\title{
PRESSEN I AABENRAA OG DENS KAAR VED NATIONALITETSKAMPENS BEGYNDELSE \\ $\mathbf{A F}$ \\ SVEND LARSEN \\ GAND. MAG., ODENSE \\ $¥$
}

$\mathrm{V}$ ed Læsningen af P. Lauridsens Fremstilling af den danske Vækkelse i Nordslesvig og af den Modstand den unge Danskhed mødte, fristes man til at spørge, om virkelig de slesvigske Byers Embedsmænd og Advokater, den slesvigholstenske Regering paa Gottorp og slesvigholstenske Kancelli i København allerede i 1838 dannede en fælles Front mod Danskheden, bunden sammen af en bevidst slesvigholstensk Indstilling. Var Modstanden mod Kochs og Fischers Blade i $1838-40$ virkelig bestemt af Myndighedernes slesvigholstenske Følelser, og skyldtes Kampen mellem Borgmester Schow i Aabenraa og Redaktøren af det derværende, efter P. Lauridsens Opfattelse ret ubetydelige, „Wochenblatt“ kun indbyrdes Drillerier uden ideel Baggrund?

Spørgsmaalets Besvarelse kræver dyberegaaende Undersøgelser af Slesvigholstenismens Sammensætning og Udvikling. Det følgende er et beskedent Bidrag til Problemets Løsning, idet Undersøgelsen blot rettes mod Pressen i Aabenraa og dens Levevilkaar; men den Kamp, som det lille Blad førte mod Myndighederne, har, som det skal vises, videre Perspektiver end almindeligt antaget ${ }^{1}$.

I 1812 døde Købmand Kopperholdt i Aabenraa og efterlod Enke og otte uforsørgede Børn. En af Sønnerne, Hans Kopperholdt, hjalp Moderen med at føre Forretningen videre, men det var ikke let. Allerede ved Faderens Død var Forholdene tvivlsomme, de følgende Aars Konjunkturer i Forbindelse med ikke velberegnede Spekulationer og Tab af et Skib fuldendte Familiens Ruin, og

1 Denne Undersøgelse er bygget paa Akter fra Slesvig-Holstenske Kancelli og den slesvigholstenske Regering paa Gottorp (Acta A. XVIII, Nr. 685 og S-H. Presse, Nr. 15) i Staatsarchiv i Kiel, samt paa Akter fra Aabenraa Raadstuearkiv og enkelte Breve fra Rigsarkivet og det kgl. Bibliothek i København. 
Enken maatte ofre hele sin Formue til Kreditorerne. Sønnen Hans forsøgte at grundlægge en ny Forretning ved Hjælp af sin Hustrus Formue og Støtte fra sin Familie, men det gik ham ikke bedre; Forretningen ødelagdes, og saa stod han da i 1823 ganske uden Midler til at forsørge Kone og fire Børn².

Som Familiefader maatte han søge nye Indtægtskilder. Det er ikke utænkeligt, at formaaende Venner har henledt hans Tanker paa Muligheden af at udgive et Blad. Kopperholdt var Nabo til Byens Borgmester Schow; fra et senere Tidspunkt vides det, at baade Schow og Provst Paulsen ydede ham virksom Bistand ved Bladets Redaktion, og det kan være Venner fra disse Mænds Kreds, han hentyder til, naar han i Ansøgningen om Privilegiet siger, at han har Forbindelser, hvorved Indsamlingen af de nødvendige Materialer fortræffeligt lettes ${ }^{2}$.

Der var i alle Tilfælde Plads for et Blad i Aabenraa. I Haderslev, Tønder og Sønderborg udkom der smaa „Intelligensblade“, men deres Betydning rakte ikke ud over den By, de udkom i. Vilde man i Aabenraa følge med i det Liv, der rørte sig udenfor Byen, læste man Hamborgaviserne, især „Altona Merkur", men „da jene deutschen Blätter nur von wenigen hiesigen Bauern gelesen und verstanden werden "3 vilde et lokalt Blad for Aabenraa og Omegn være nyttigt.

Siden 4. Maj 1820 gjaldt imidlertid den Bestemmelse, at ingen Dag- eller Ugeblade maatte udkomme, uden at Udgiveren var forsynet med et Privilegium ${ }^{4}$. Kopperholdt indsendte derfor en Ansøgning til Kongen, hvori han fremførte, hvad der talte for at han fik et saadant Privilegium, og for at Bladet kunde sikre hans Familie Underhold, bad han om, at det maatte blive et "udelukkende " Privilegium, d.v. s. et Privilegium, der gav ham Eneret paa at udgive et Blad for Aabenraa og Løgumkloster Byer med tilliggende Amter, og endelig bad han om at faa Privilegiet gratis ${ }^{5}$.

I den følgende Tid blev Ansøgningen overvejet af de forskellige Myndigheder: Herredsfoged Suhr, Amtmand Stemann, Magistraten i Aabenraa, Statholderen Carl af Hessen, og endelig indgav slesvigholstenske Kancelli sin Forestilling til Kongen ${ }^{6}$, hvorefter Kongen resolverede, at Kopperholdt skulde

1 Kopperholdts Ansøgning om Privilegium, 30/5, 1823 (Acta A. XVIII. Nr. 685) Magistratens Betænkning desang. $2 / 7$, 1823. (Smst.) ${ }^{2}$ Kopperholdts anf. Ansøgning. 3 Amtmand Stemanns Betænkning om Kopperholdts Ansøgning 2/\%, 1823 (Smst.). 2 Chronologische Sammlung der im Jahre 1820 ergangene Verordnungen und Verfügungen für die Herzogthümer Schleswig und Holstein (cit. „Chron. Samml."). 5 Kopperholdts Ansøgning 30/5, I823. - 5/4, 1825. (Acta A. XVIII. Nr. 685). 
have et gratis og udelukkende Privilegium paa Udgivelsen af et Blad for Aabenraa og Løgumkloster med tilliggende Amter. Privilegiet blev underskreven d. 26. April 1825 .

Der var dog knyttet visse Betingelser til et saadant Privilegium. De Myndigheder, der havde givet Betænkning om Ansøgningen, var enige om, at Redaktøren skulde optage kgl. Bekendtgørelser gratis, og dette indføjedes i Privilegiet. Derimod havde der været afvigende Meninger om Betingelserne for Myndighedernes officielle Annoncer, Herredsfoged Suhr havde tænkt sig Muligheden af helt at nægte ham Betaling for saadanne Annoncer, der i de andre Byer var meget dyre ${ }^{2}$, og Magistraten i Aabenraa havde stillet sig paa samme Maade ${ }^{3}$. Amtmand Stemann mente derimod, at der skulde betales $1 \frac{1}{2}$ Sk. Kurant pr. Linie, naar Annoncen bestaar af 5 Linier, men I Sk. Kurant, naar den bestaar af mere end 5 Linier, hver Linie paa 13 Stavelser ${ }^{4}$. Men Kancelliet tog ikke Hensyn til nogen af disse Forslag. Det bestemte, at den stedlige Øvrigheds Annoncer skulde optages for $3 \frac{1}{5}$ Sk. pr. Linie, og derved blev det.

Et Punkt i Privilegiet, der er af særlig Vigtighed og Interesse, er Spørgsmaalet om Bladets Forhold til de politiske Efterretninger. Da Spørgsmaalet senere atter og atter kom frem, er det paa sin Plads her at give en kort Udsigt over den bestaaende Presselovgivning.

Grundlaget for denne er Forordningen af I4. Sept. I770, der tilstod uindskrænket Frihed for Pressen, saaledes at ingen skulde være forpligtet til at overgive deres Bøger og Skrifter til Censur. Men dog maatte, iflg. Forordn. af 18. Oktbr. I 77I, Forfatteren staa til Ansvar for, at Skrifternes Indhold ikke stred mod Lovene, og alle Injurier og oprørske Skrifter er undergivet Straf. Denne Pressefrihed indskrænkedes I. Novbr. I 799. Det paalagdes Øvrigheden at have Opmærksomheden rettet imod de modvillige Forfattere og advare dem, eventuelt paalægge Beslag af det trykte, og i visse Tilfælde overgive Sagen til retslig Afgørelse. Trods disse Indskrænkninger havde det samlede danske Monarki dog Pressefrihed. Bruddet med den hidtil fulgte Linie kom først omkring 1820. I Overensstemmelse med den reaktionære Bevægelse i Udlandet, den skarpe Forfølgelse af alle politiske Frihedsrørelser, indskærpede en Kancelliskrivelse af $19 / 5$ I 8 I 8 , at Myndighederne maatte vaage over, at Pressen ikke benyttedes til Injurier mod fremmede Regeringer, og da det tyske Forbund d. 20/9 I8I9 nærmere havde bestemt Grænsen for Pressefriheden, kom disse Bestem-

1 Privilegiet ligger som Bilag til Skrivelse fra Slesvigs Overret til S-H. Regering ${ }^{27} / 3,1839$. (S-H. Presse 15.) ${ }^{2}$ Suhrs Betænkning, ${ }^{25} /$, 1823 . (Acta A. XVIII. Nr. 685.) ${ }^{3}$ Magistratens Betænkning $2 / 7,1823$ (Smst.). * Stemanns Betænkning $2 / 7,1823$ (Smst.). 
melser ogsaa til at ramme Holsten. ${ }^{9} / 11$ I8I9 maatte Kongen forordne, at fremtidig maatte ingen Skrifter under 20 Ark udkomme i Holsten uden at være censurerede; der ansattes Censorer i Kiel og Altona for Skrifter, medens Ugeog Dagblade censureredes af det stedlige Politi. Dermed var der sat et Skel mellem Slesvigs og Holstens Presseordning. Fra nu af havde Holsten virkelig Censur; i Slesvig vedblev Pressefriheden at bestaa af Navn. Men „paa Grund af de nuværende Tidsomstændigheder og de $i$ andre Stater trufne Forholdsregler" skærpedes Tilsynet med Pressen i Slesvig $22 / 2$ I 820 . Før Fordelingen af et trykt Skrift skulde Bogtrykkeren sende et Eksemplar til Politimesteren, og hvis Politimesteren fandt, at Skriftet overtraadte de bestaaende Love eller krænkede en fremmed Stats Forvaltning, skulde han beslaglægge det og indberette Sagen til Overretten til videre Behandling. Det var unægtelig et betydeligt Minus i Slesvigs Pressefrihed, ja, i Virkeligheden var Slesvig nu daarligere stillet end Holsten. Thi det var dog bedre for en Redaktør, at han i Holsten før Trykningen af sit Blad kunde forelægge Manuskriptet for Censor til Godkendelse, end at han, som i Slesvig, først efter at Bladets Oplag var trykt skulde have det godkendt og saa kunde risikere, at Oplaget blev beslaglagt.

Yderlig vanskelige blev Forholdene efter at Kancellipatentet af $4 / 3$ I 820 var udstedt. Thi ikke blot krævede det, som før sagt, at alle Udgiverne af Dag- og Ugeblade i Slesvig og Holsten fra nu af skulde være forsynede med et Privilegium, men det forbød ogsaa Udgiverne at optage „politiske Efterretninger eller Artikler, der beskæftiger sig med politiske Genstande" uden speciel Tilladelse $i$ Privilegiet ${ }^{1}$. Her var et Punkt, der kunde blive Grundlag for adskillige Stridigheder.

Kopperholdt havde ikke i sin Ansøgning bedt om Lov til at optage politiske Efterretninger, men Magistraten havde foreslaaet, at han fik Lov at bringe politiske Meddelelser fra andre Blade ${ }^{2}$. Dette nærede Statholderen Carl af Hessen Betænkeligheder ved $^{3}$, Kancelliet stillede sig paa samme Standpunkt ${ }^{4}$, og i Overensstemmelse dermed forbød Privilegiet ham at optage politiske Efterretninger. Dette blev, som vi senere skal se, skæbnesvangert for Kopperholdt.

Kopperholdt havde nu Privilegium som Bladudgiver; tilbage stod at faa Bladet trykt.

Det har nok været $i$ hans Tanker selv at anskaffe sig en Bogtrykkerpresse ${ }^{5}$,

1 Disse og de tidligere anførte Forordninger er optaget i Chronol. Saml. ${ }^{2}$ Magistratens Betænkning $2 / 7$, I823. (Acta A. XVIII. Nr. 685.) ${ }^{3}$ Carl af Hessens Betænkning ${ }^{17} / 11$ r824. (Smst.). (Smst.). 
men det blev der lagt Hindringer i Vejen for, thi den 15. Marts I825, altsaa en god Maaned før Kopperholdt fik sit Privilegium, havde een af hans Medborgere Rathje faaet Privilegium som Bogtrykker i Aabenraa ${ }^{1}$. Rathje havde i Altona bestilt de nødvendige Apparater til Trykkeriet og haabede paa, at han nu ved at udgive et lille Intelligensblad kunde skaffe sig et passende Udkomme. Stor var derfor hans Overraskelse, da han, der en Dag i Maj Maaned var gaaet op til Borgmester Schow for at vise ham Privilegiet som Bogtrykker, af denne fik at vide, at Kopperholdt netop havde faaet Privilegium som Bladudgiver. I sin Nød indsendte Rathje en Ansøgning om at maatte udgive et Intelligensblad $^{2}$, men Kancelliet afslog Ansøgningen fuldstændig ${ }^{3}$. Det naturligste var da, at Kopperholdt og Rathje gik i Samarbejde. Den Kontrakt de sluttede, er oplysende for de Kaar, hvorunder Pressen dengang virkede i Aabenraa.

Rathje forpligter sig paa sin Side til at trykke Ugebladet passende og prompte; han maa ikke have for store Mellemrum mellem Artiklerne, og navnlig skal Annoncerne trykkes saa tæt som muligt. Spalterne skal være paa 55 Linier, og Kopperholdt maa bestemme, hvordan de forskellige Bogstaver, Tal og Linier, der findes i Trykkeriet, skal anvendes. I det hele taget skal Rathje følge Kopperholdts Anvisninger, hvis han da ellers som Bogtrykker kan anerkende dem som rigtige*.

Paa Grund af Foretagendets Usikkerhed maa Kopperholdt udgive Bladet under hvad Titel han lyster og større eller mindre, som han vil, men han skal meddele Rathje et kvart Aar i Forvejen, naar der skal ske Forandringer. Iøvrigt maa Kopperholdt udgive Bladet to Gange om Ugen, eller ogsaa een Gang. Rathje faar 6 Mark Kurant for Trykningen af hvert Oplag under 300 Eksemplarer, og dette Beløb skal Kopperholdt betale kontant, hver Gang han modtager Bladet. Papiret skal Kopperholdt levere, og det skal være godt skikket til Trykning, det maa ikke være kornet. Manuskripterne skal være korrekte og læselige, og da Bladet hovedsagelig er bestemt for Meddelelser af Efterretninger, der kommer med Hamborg Posten og den danske Post, bestemmes der om Tiden for Manuskripternes Indlevering, at der til hvert Nummer skal holdes en Reservespalte rede til Indrykning, og alt, hvad der kan sættes før Hamborg Posten kommer, skal sættes. Til Sætning af de Efterretninger, som indleveres Onsdag og Lørdag Aften efter Hamborg Postens Ankomst, har Rathje tre Timer til hver Spalte, men til Efterretninger, som kommer med den jydske Post, kun en Time, men Kopperholdt er forpligtet til at lade Manuskripterne følge saa

1 Kopi af Rathjes Privilegium 15/3 I 825. (Acta A. XVIII. Nr. 685.) 2 Ansøgning fra Rathje 27/6 1825. (Smst.) $318 / 6$ 1825. (Smst.) \& Kontrakt mellem Kopperholdt og Rathje $23 / 9$ 1826. (Smst.). 
hurtigt efter hinanden, at Rathje ikke skal tøve. Til Korrektur og til Trykning af Bladet fastsættes $2^{1} / 2$ Time. Endelig forpligter Rathje sig til at hemmeligholde Manuskripterne, og Overenskomsten fastsættes til at vare i Io Aar fra I.Jan. I 826.

Trods disse udførlige Bestemmelser blev Samarbejdet mellem Redaktør og Bogtrykker ikke uden Rivninger. Kopperholdt havde utvivlsomt de bedste Kort paa Haanden efter Kontrakten, og da Rathjes Privilegium ikke gav ham Eneret som Bogtrykker i Aabenraa, kunde Kopperholdt altid true med enten selv at ville oprette et Trykkeri eller lade Bladet trykke et andet Sted.

Allerede i 1829 paastod Rathje, at Kopperholdt ikke overholdt Kontrakten. Sagen kom for Overretten, som imidlertid lagde den hen ${ }^{1}$. Men i 1834 henvendte Rathje sig til Kancelliet med en Besværing. Han paastod, at Kopperholdt var urimelig i Kravene til ham, og for at hindre, at Kopperholdt skulde faa Lov at trykke Bladet selv, bad han om at faa et udelukkende Privilegium som Bogtrykker i Aabenraa ${ }^{2}$. Kancelliets Svar blev imidlertid et Afslag ${ }^{3}$, thi ikke blot beklagede Kopperholdt sig i kraftige Udtryk over Rathjes løgnagtige Beskyldninger, men han paastod ogsaa, at Trykningen baade var'slet og forsinkedes ${ }^{4}$, og Magistraten saavel som den slesvigske Overret støttede Kopperholdt ${ }^{5}$. Ganske vist, bemærker Magistraten, stiller Redaktøren store Krav til Trykkeren, men det maa dog bemærkes, at Rathje med et ubegribeligt Egensind slet ikke vil anerkende nogen Fejl; Tryk og Sværte er daarligt, og ofte forsinker han Trykningen for at gøre sine Fordringer gældende. Trods disse Stridigheder fornyede Kopperholdt og Rathje dog deres Kontrakt 30. Dec. I 835 for fire Aar. Denne Kontrakt afviger fra den foregaaende ved i højere Grad at sikre Rathjes Stilling. Tryk og Format skal være som før, og Kopperholdt skal udgive Bladet to Gange om Ugen: Tirsdag og Fredag, hver Gang et halvt Ark, og hvis det skal blive nødvendigt, kun at udgive det een Gang, skal det komme om Fredagen. Oplaget er ogsaa bleven noget mindre, men Prisen for Trykningen noget højere. Medens Kopperholdt i 1826 skulde betale $6 \mathrm{Mk}$. for Trykning af $300 \mathrm{Ekspl}$. skal han nu betale $7 \mathrm{Mk} .8 \mathrm{Sk}$. Kurant for $200 \mathrm{Ekspl}$. Bestemmelserne om Tiden for Manuskripternes Indlevering er udeladt, men i Stedet er der fastsat Priser for Korrekturer, og Kopperholdt maa ikke mere bestemme, hvordan Trykkeriets forskellige Typer skal anvendes ${ }^{6}$.

Denne Kontrakt bestod indtil Kopperholdt i I 839 lod Bladet trykke i Flensborg.

\footnotetext{
$12 / 11$ 1832. (Acta A. XVIII. Nr. 685.)

$218 / 3$ 1834. (Smst.). $38 / 7$ 1834. (Smst.). 4 $28 / 4$ I834. (Smst.). 3 30/. og 16/6 1834. (Smst.). $30 / 12$ 1835. (Afskrift i Aabenraa Raadstuearkiv.)
} 
I de første 8-9 Aar af sin Levetid adskilte "Allgemeines Wochenblatt" sig ikke synderligt fra de andre slesvigske „Intelligensblade“. Udgivelsen af Bladet var nærmest en Forretning, der skulde skaffe sin Redaktør Udkomme; det var ikke, saaledes som „Dannevirke“ senere, oprettet for at tjene en Idé. Dets Opgave var kun den at bringe Borgerne i Aabenraa og Omegn Handelsefterretninger og Skibslister, samt at give Plads for Øvrighedens Bekendtgørelser og private Annoncer. Disse Rubrikker er saa vidt muligt faste, og som Regel fylder de Halvdelen af Bladets 8 Spalter. Resten af Bladet optages af meget blandet Stof. Der kan være Nyheder fra København eller andre Byer i Kongeriget, men det har Tilfældighedens Præg, og oftest er det taget fra andre Aviser, eller der kan være Meddelelser hentede fra tyske Aviser især fra „Børsen-Halle“, som udkom i Hamborg, eller fra „Allgemeine Anzeiger der Deutschen“, som udkom i Leipzig, og den Plads, Nyhederne levnede, fyldtes ud af Beretninger om alle Slags mærkelige Fænomener, Rejsebeskrivelser og moralske Fortællinger, som Redaktøren kunde finde i „Literarische Miscellen“, „Blätter für literarische Unterhaltung “, „Lesefrüchte vom Felde der neuesten Literatur“, „Der Eremit" og andre tyske periodiske Skrifter. Bag alt dette søger man forgæves ledende Tanker, Ideer, der kæmpes for, og som kan give Bladet en Tendens. Men følger man Bladet fra Aar til Aar i Trediverne, vil man se, hvor forholdsvis hurtigt det omkring 1834 skifter Karakter, og hvorledes alt det, der før var Fyldekalk, forsvinder, og i Stedet bliver det et politisk Organ, et Redskab for en ny Tids Tanker, som i lidenskabelig Polemik ikke staar tilbage for „Kieler Correspondenzblatt“ eller „Kjøbenhavnsposten“, og som ufortrøden tager Kampen op mod Myndighederne.

Bladets farveløse Præg i de første Aar betød næppe, at Kopperholdt var ligegyldig for offentlige Anliggender, men skyldtes mere, at han ikke vovede at lægge sine Meninger for Dagen. Hans Stilling til Lornsensagen i r83o kan tyde paa det.

I de første Dage af November 1830 havde Lornsen sammen med liberale Mænd i Holsten forberedt Udsendelsen af sit Programskrift „Uber das Verfassungswerk in Schleswig-Holstein " med Kravet om en repræsentativ Forfatning for Slesvig og Holsten, og Hertugdømmerne i Personalunion med Kongeriget. Skriftet blev godkendt af Censor og i Dagene omkring 5. November spredt ud over Slesvig og Holsten.

En Aften sad Professor Michelsen i et Selskab hos Advokat Witte i Kiel. Han blev da af de tilstedeværende Venner opfordret til at skrive til en Bekendt $i$ Aabenraa, hvor Michelsen havde henlevet sin Barndom, for at faa Lornsens 
Skrift udbredt der. Først agtede han at skrive til Borgmester Schow om Sagen, men da han ikke vilde bebyrde ham med Skriftets Fordeling, skrev han til Kopperholdt, antagelig 5. November. Men et Par Dage efter sendte han ogsaa Schow et Brev, der giver et levende Udtryk for de bevægede Dages Stemning ${ }^{2}$. Michelsen skrev til ham „, højvigtigt Anliggende“ i Følelsen af, at han nu stod Schow ganske nær! „Thi netop i Deres Hus er der ganske tidligt gaaet et Lys op for mig, eller i det mindste vakt en rigtigere Følelse for Stat og Folkeliv, thi mere kunde det ikke være i min daværende Alder. Jeg hørte hos Dem frisindet Underholdning, var altid til Stede ved Forelæsningen af „Kieler Blätter“, hvoraf hvert Hefte blev hilst med Jubel, og meget af M. Arndts Skrifter gemte jeg i mit Hjerte. " Michelsen minder videre om, hvorledes Schow gik i Spidsen for en Petition fra Aabenraa Magistrat om Opretholdelse og Ukrænkelighed af Enigheden mellem Slesvig og Holsten. Denne Enighed skal, om vi forbliver dygtige og patriotiske, aldrig sønderrives. Nu indsamles der Underskrifter paa en Petition om en Forfatning. Den er allerede underskreven af mere end hundrede $i$ Kiel, men fra alle Land- og Bykommuner maa der indgaa Petitioner, for Tiden kan ikke nøjes med en landstændersk Forfatning, den maa have virkelig Folkerepræsentation.

Brevet giver et Indtryk af Schows Hjem som Samlingssted for en Kreds af Mennesker, der frisindet har drøftet Hertugdømmernes Anliggender i Aarene omkring I8I6. Brevet er et Vidnesbyrd om, at Slesvigholstenismen havde Grobund ogsaa udenfor Kiel. Men nu i I830 er Schows Stilling bleven en anden. Uden at fornægte sit tidligere Standpunkt svarer han køligt, at Michelsen tager forkert, hvis han tror, at han, Schow, vil virke for den omtalte Sag. Ikke blot hindrer hans Stilling som Embedsmand ham deri, men han anser ogsaa Tiden for uskikket og hele Planen for ordensstridig og højst farlig paa Grund af Tidens Tendens. Lignende Uroligheder som i Belgien vil man dog vel ikke udbrede $\mathrm{i}$ vort elskede Fædreland, spørger han, og han formener, at de, der staar i Spidsen for den i Landet forvoldte Ophidselse, ikke har betænkt, hvad det kan føre til ${ }^{3}$.

Saa køligt Schow end svarede Michelsen, betød det ikke, at han ganske misbilligede de Ideer, der bar Lornsens Skrift. Det viste hans Stilling til Kopperholdt.

Michelsen havde sendt en Ekspres til Aabenraa med Opfordring til Kopperholdt om at meddele Læserne Lornsens Skrift, og han ledsagede det med en

1 Ekstrakt af Protokollen for Undersøgelseskommissionen i Lornsensagen. Rendsborg d. 12/1 1831. (Aabenraa Raadstuearkiv.) 2 Brevet er dateret d. $\% 11830$. 8 Schow til Michelsen 18/11 1830. (Koncept i Aabenraa Raadstuearkiv.) 
Følgeskrivelse ${ }^{1}$. Derefter meddelte Kopperholdt i Bladet for 8. November, at Lornsens Skrift var kommen, og dets sejrende Kraft gjorde sig gældende. Der forberedtes Petitioner, og de slesvigske Byer maatte mindst af alle staa tilbage, da Holsten vel nu faar en Forfatning og saaledes rykker op i de tyske konstitutionelle Staters Række, „men for Slesvigs Vedkommende kan der ovenfra rejses en Tvivl, som vi nedenfra ikke maa lade komme frem".

I Bladet for I I. November skrev Kopperholdt yderligere, at Lornsens Skrift har skabt en stærk Bevægelse, da det har gjort opmærksom paa Faren for, at Slesvig muligvis kan blive skilt fra Holsten og forbunden med Danmark; det har tændt et Lys for Slesvigholstenerne over deres vigtigste Anliggende, som aldrig mere kan slukkes. Højt og almindeligt udtales det Ønske, at begge Hertugdømmer i Fællesskab skal have en repræsentativ Forfatning. Og hvorfor skulde Kongen ikke give det, han, der er Fader for sine Undersaatter, han, der er Oplysningens virksomste Fremmer, han, der billiger Udsættelsen af Præmier til Fællesaandens og Nationalaandens Oplivelse, skulde han ikke gerne høre et elskende Folks Onsker, som det frembærer, idet det beder om en bedre Indretning af Statshusholdningen. „Gud bevare Kongen!“ slutter Kopperholdt.

I nervøs Iver havde Regeringen straks efter at Lornsens Skrift udkom, foranstaltet omfattende Undersøgelser for at skaffe Klarhed over Bevægelsens Omfang og Karakter, og Artiklerne i „Allgemeines Wochenblatt“ undgik ikke dens Opmærksomhed.

Dagen efter at Schow havde sendt Svaret til Michelsen afkrævede Overretten Schow en Erklæring om, hvorledes han havde kunnet tillade, at et Blad med en Artikel som den i Nummeret for 8 . November kunde udbredes, og den anmodede Borgmesteren om at tage Kopperholdt i Forhør ${ }^{2}$. I Forhøret den 14. November erklærede Kopperholdt, at han havde læst Lornsens Skrift og oprigtigt maatte tilstaa, at det havde givet ham den Overbevisning, at en representativ Forfatning maatte faa lykkelige Følger for begge Hertugdømmer. Han havde gennem den høje kongelige Embedsmands Skrift faaet den Opfattelse, at Regeringen ikke vilde have noget imod en saadan Forfatning, naar blot Undersaatterne viste Interesse derfor; ja, agtværdige Mænd havde endog fortalt, at Kongen selv havde læst Lornsens Skrift og havde tilladt Trykningen. I Tvivlstilfælde plejede Kopperholdt at hente Raad hos Provst Paulsen og Borgmester Schow, og sidstnævnte var da ogsaa bleven spurgt i dette Tilfælde ${ }^{3}$.

1 Schow til Overretten $4 / 121830$ og Michelsen til Schow $16 / 11$ 1830. (Aabenraa Raadstuearkiv.) 2 Overretten til Schow 13/11 I830. (Aabenraa Raadstuearkiv.) 3 Ekstrakt af Aabenraa Retsprotokol 14/11 1830. (Smst.) 
Schow erklærede for sit Vedkommende, at han ikke havde fundet noget at indvende mod Artiklens Opfordring til at indsende Petitioner, saalidt som mod Artiklens Omtale af Lornsens Skrift, da dette allerede havde passeret Censuren i Kiel og nu var udbredt over hele Byen ${ }^{1}$.

Sagen forfulgtes videre af Regeringen, indtil den havde faaet oplyst, at Artiklen i Bladet for 8. November var et Brudstykke af Michelsens Følgeskrivelse, men noget ændret af Kopperholdt ${ }^{2}$. Det er saaledes vanskeligt at sige noget bestemt om Kopperholdts Stilling til Lornsen-Bevægelsen paa Grundlag af Artiklen d. 8. November; men til Gengæld er der en saa stor Overensstemmelse mellem Artiklen d. II. November og Kopperholdts Udtalelser i Forhøret d. I4. November, at man vist kan fastslaa, at denne Artikel er et virkeligt Udtryk for Kopperholdts Overbevisning og et Vidnesbyrd om, at Lornsens Skrift har sat Tanker og Følelser saa stærkt i Bevægelse hos ham, at det, for at tale med hans egne Ord, har tændt et Lys, som aldrig kan slukkes. Overfor dette kan det næppe tillægges saa stor Betydning, at han i sit Blad for 15 . November med alle Tegn paa Anger meddeler, at det af "flere agtede Mænd“ er bebrejdet ham, at han har indrykket Artiklen i Bladet for 8. November, og at han forsikrer, at han har indset, at han har handlet overilet og beder Læserne om at forstaa, at det skyldes kun en fejlagtig Anskuelse, ikke et slet Sindelag, og at han er gennemtrængt af den dybeste Ærbødighed for den milde og retfærdige Konge, saa han „sammen med alle taknemlige og trofaste Undersaatter glad vil ofre sit Hjerteblod for den elskede Landsfaders hellige Person". Denne Artikels Tone har en paafaldende Lighed med et Udkast til en Artikel af Provst Paulsen dateret i3. Novbr., som ligger blandt denne Sags Akter ${ }^{3}$.

Spørgsmaalet om Kopperholdts og Myndighedernes Stilling til Lornsensagen er behandlet saa udførligt, fordi det giver Indblik i Bevægelsens Virkning og Karakter i Aabenraa og tjener til bedre at forstaa Myndighedernes Stilling til Kopperholdts Blad senere. Det er dog først efter I 834 at der igen kommer Konflikt mellem Redaktøren i Aabenraa og Regeringen, og det skete først da der var oprettet en ny Forvaltningsinstitution i Slesvig og Holsten.

I Forordningen om Provinsialstændernes Oprettelse (28. Maj 183I) havde Kongen ladet bekendtgøre, at i Hertugdømmerne skulde Forvaltningen skilles

1 Schows Erklæring til Overretten 14/11 I83o. Aabenraa Raadstuearkiv. ${ }^{2}$ Schow til Overretten $4 / 12$ 1830. (Smst.), smlgn. Ekstrakt af Protokollen for Undersøgelseskommissionen i Lornsen-Sagen, Rendsburg ${ }^{12} / 1$ I 83 I. (Smst.) ${ }^{3}$ (Smst.) 
fra Retsvæsenet. Dette skete 1834 . Samme Dag, som Forordningen om den nærmere Ordning af Stænderne i Hertugdømmerne udstedtes (15. Maj 1834), kom ikke alene Forordningen om Oprettelsen af en Overappellationsret med Sæde i Kiel, men ogsaa en provisorisk Instruktion for en Provinsialregering for Slesvig og Holsten, som skulde have til Huse paa Gottorp. Provinsialregeringen fik overdraget Forvaltningen af Hertugdømmerne med enkelte Undtagelser. Ogsaa for Pressen fik det Betydning. Instruktionens § I9 lød nemlig saaledes: „Regeringen fører Tilsyn med Pressen og søger at modvirke Misbrug af den. Den har derfor at beslaglægge Skrifter, der er forbudt og strider mod de nu gældende Presselove, og den skal uopholdelig indsende en Anmeldelse om hver Beslaglæggelse til Kancelliet, gøre de ansatte Censurembedsmænd opmærksom paa Pligtforsømmelser og afgøre eventuelle Besværinger over disses Handlinger.“

Naar en Censurmyndighed - som Reglen Politimesteren - beslaglagde et Blad, blev Forretningsgangen for Slesvigs Vedkommende efter Regeringens Oprettelse den, at Gensor sendte Meddelelse om Beslaglæggelsen til Gottorpregeringen $^{1}$; derefter kunde Udgiveren enten selv, eller ved en Sagfører henvende sig til Regeringen og besvære sig over Beslaget.

Ved denne Ordning, som ved Presseordningen i Slesvig i det hele taget, var der dog Mangler, som viste sig, da Kampen mod Liberalismen i Tredivernes sidste Halvdel begyndte.

Forordningen om Stændernes Indførelse havde $\mathrm{i}$ de politisk interesserede Kredse vakt en livlig Drøftelse af offentlige Anliggender. Ifølge Kancellipatentet af 4. Marts I820 og i Henhold til Privilegierne var det forbudt Bladudgiverne at beskæftige sig med politiske Anliggender. Kun „Altona Merkur“ og „Glückstadt Fortuna" dannede i denne Henseende en Undtagelse ${ }^{2}$. Jo længere man kom hen imod den første Stænderforsamlings Aabning i 1 835, jo mere mærkede man imidlertid, hvorledes det politiske Stof sivede ind i Aviserne, og det skete længe uden Indgreb fra Myndighedernes Side.

Det førende Blad var i denne Henseende „Kieler Correspondenzblatt“, som var oprettet i i 830 alene for at tjene en politisk Idé, Liberalismen. Ved Siden af det kom i Løbet af Trediverne til at staa „Eckernförder Wochenblatt“ og lidt senere Kopperholdts Blad „Allgemeines Wochenblatt“. 26. September 1835 meddelte det slesvigholstenske Kancelli imidlertid Gottorpregeringen, at Meddelelser om Stænderforhandlinger kun maatte tilstedes, naar de toges fra Stændertidende, og Meddelelser i Udtog fra disse, som indeholder Forvanskninger,

1 Saaledes betegnes i det følgende den slesvig-holstenske Regering paa Gottorp. ' 2 Gottorpregeringen til S-H. Kancelli, 19/12 1835. (Acta A. XVIII. Nr. 685.) 
skal forbydes ${ }^{1}$. Dette Reskript gav straks Anledning til en Beslaglæggelse af „Eckernförder Wochenblatt", skønt den beslaglagte Artikel var taget fra „Kjøbenhavnsposten“ og indeholdt nogle teoretiske Betragtninger over Statens finansielle Tilstand, altsaa en rent politisk Artikel, men ikke en Artikel, der kunde siges at stride mod Reskriptet af ${ }^{26} / 9$, og dertil kom ydermere, at Artiklen var bleven tilladt $i$ „Allgemeines Wochenblatt“. Censor holdt sig imidlertid til Reskriptet, og Beslaglæggelsen foraarsagede en betydningsfuld Drøftelse af Presseforholdene i Slesvig. Uden at komme nærmere ind paa Beslaglæggelsen skal der her gøres Rede for det Standpunkt, Gottorpregeringen og Kancelliet indtog, da det er bestemmende for disse Myndigheders Holdning i den følgende Tid.

Gottorpregeringen fremhævede Nødvendigheden af at faa faste Regler for Behandlingen af Pressesager. Efter dens Instruktion kan den nok ophæve et Beslag, men det er tvivlsomt, om Regeringen kan bekræfte et Beslag definitivt. Reglerne maa tages fra Lovene. Før Gottorpregeringens Oprettelse var disse klare nok, thi da skulde Overretten afgøre Beslaglæggelsen, men efter at Retsvæsen og Forvaltning er bleven adskilt, stiller Sagen sig anderledes. Instruktionen siger, at Regeringen har Ret til midlertidigt at beslaglægge, men Tvivlen opstaar derved, at Instruktionen ogsaa paabyder, at Beslaglæggelsen skal meddeles Kancelliet, og fordi de bestaaende Love taler om, at Sagen kan henvises til Afgørelse af Retten. Imidlertid taler det, at Instruktionen tildeler Regeringen Opsyn med Pressen, for, at Gottorpregeringen ogsaa har den endelige Afgørelse af Beslaglæggelsessager, og det tilkommer den at afgøre Besværinger over Censurmyndighederne, og det maa saaledes afhænge af Regeringen, om den vil overvise Sagen til retslig Kendelse. Dog maa man for Dagspressens Vedkommende huske paa, at Redaktørerne skal have et Privilegium, og de fleste af Privilegierne siger, at Udgiveren er ansvarlig for Bladets Indhold; med Hensyn til Privilegiets Fortolkning maa han underkaste sig Kancelliets Kendelse, og naar Gottorpregeringen derfor finder, at en Bladudgiver skal straffes med at miste sit Privilegium, skal Sagen ikke henvises til Retten, men til Kancelliet.

Men vanskeligst er Spørgsmaalet om, hvorledes man skal stille sig til de politiske Artikler. Det er jo i de fleste Bladprivilegier forbudt Udgiverne at beskæftige sig saavel med indre som med ydre Politik. Gottorpregeringen erkender, at man ikke hidtil har taget det saa nøje med dette Forbud, men dermed er ikke sagt, at Regeringen ikke kan lade denne Overbærenhed ophøre overfor Blade, som viser en fjendtlig Tendens, men Regeringen finder det ingenlunde tilraadeligt at forbyde de andre Blade politiske Artikler.

1 Chron. Samml. 
Kancelliet var i Hovedsagen enig med Gottorpregeringen ${ }^{1}$, men det betoner stærkt, at efter Adskillelsen af Retsvæsen og Forvaltning, gik alle Politisager over til Gottorpregeringen, og til disse hører Presseforholdene. Som Middel til at hindre Misbrug af Pressen har Regeringen faaet Myndighed til Beslaglæggelse, og derom skal der kun gives en „Meddelelse“ til Kancelliet. Gottorpregeringen kan altsaa bekræfte et Beslag definitivt, og Regeringens Kendelse udelukker Henvendelse til Retten; kun naar Regeringen vil have en yderligere Straf end Beslaglæggelse paalagt, maa denne paadømmes af Retten. Men, bemærker Kancelliet, Regeringen er utvivlsomt enig med os $i$, at uden tvingende Nødvendighed maa Rettens Indskriden ikke foranlediges.

Hvad Redaktørernes politiske Efterretninger angaar „kan den kongelige Regerings Ret til at føre dem tilbage indenfor de af dem delvis overskredne Grænser ikke drages i Tvivl“", og Kancelliet har derfor intet imod, at Regeringen truer enkelte genstridige med $\mathrm{Tab}$ af Privilegiet.

Denne Fortolkning af Gottorpregeringens Instruktion tjener til Forstaaelse af den Holdning, Myndighederne indtog overfor "Allgemeines Wochenblatt“ i Aabenraa.

Siden Lornsen-Affæren havde Kopperholdt saa temmelig haft Fred for Myndighederne. Forholdet til Rathje voldte derimod Vanskeligheder, og Bladet var nok i Tilbagegang, thi det var hans Tanke fra I. Juli 1835 at indskrænke Bladet, saa det fra at udkomme to Gange fremtidig kun skulde udkomme een Gang ugentlig - en Indskrænkning, som dog først fandt Sted April ı 836. Tanken om Indskrænkningen foranledigede imidlertid Rathje til at ansøge om ogsaa at faa Privilegium paa at udgive et Blad ${ }^{2}$. Han motiverede den med, at Indtægterne ved Trykningen af „Allgemeines Wochenblatt“ gav ham saa ringe Fortjeneste, at han, selv gennem en eksemplarisk Levemaade, næppe kunde skaffe det nødvendige til Livets Ophold for sig og sin Familie. Efter hans Mening bekymrede Kopperholdt sig ikke stort om Bladet, og hvis Bladet bliver yderligere indskrænket, kan Rathje ikke klare sig. Derfor vil han nu udgive et nyttigt Blad uden al politisk Tendens.

Rathje har vel ment, at der i den sidste Bemærkning laa en Anbefaling. Kopperholdts Blad var nemlig ved at blive en hel Del politisk. Den tidligere Fyldekalk af moralsk og belærende Læsning hentet fra tyske Tidsskrifter var ved at afløses af politiske Artikler hentet fra „Kieler Correspondenzblatt“, „Eckernförder Wochenblatt“ eller „Kjøbenhavnsposten“.

${ }^{1}$ S-H. Kancelli til Gottorpregeringen $23 / 6$ 1 836 . (S-H. Presse, I5.) ${ }^{2}$ Ansøgning fra Rathje 12/4 1835. (Acta A. XVIII. Nr. 685.) 
Denne politiske Tendens syntes imidlertid at stemme med Ønsker i Bladets Læsekreds. Allerede i 1834 havde Kopperholdt udtalt i Anledning af Rathjes Ansøgning om at faa udelukkende Privilegium som Bogtrykker i Aabenraa, at hvis Rathje fik et saadant Privilegium, vilde „den ganske naturlige Følge deraf vel være, at mit Blad ophører at komme i dets nuværende Tendens og maa udkomme som rent Intelligensblad"1. Ligesaa karakteristisk er Magistratens Betænkning om Rathjes Ansøgning om at faa Privilegium paa at udgive et Blad, thi næsten spottende bemærkes det, at der næppe er Plads for et Blad uden al politisk Tendens, hvori blot Skønlitteratur, Historie og Fædrelandsbegivenheder, korte Digte, Biografier af fortræffelige Mænd, Landbrugets Kultur og Økonomi, passende Anekdoter og Intelligens optages, thi man er saa overfyldt af Lesefrüchte, Abendzeitung, Zeitung für die elegante Welt, Modejournale, PfennigMagazine, at man ikke ønsker flere af den Slags ${ }^{2}$. Derfor fik Rathje Afslag paa sin Ansøgning ${ }^{3}$.

Det vides ikke, at Borgmester Schow nogensinde beslaglagde Bladet, trods det voksende politiske Stof. Han fik tværtimod en Tilrettevisning fra Gottorpregeringen i Anledning af, at han havde ladet en Artikel passere, som omtalte en Pressesag mod Professor David, og det betydedes ham, at den Omstændighed, at en Artikel var trykt $i$ et andet offentligt Blad - som i dette Tilfælde - ikke gjorde Optagelsen tilladelig4.

Tilrettevisningen medførte, at Kopperholdt en Tid forelagde Manuskriptet til Godkendelse for Trykningen ${ }^{5}$, men den Ordning var kun en privat Aftale mellem Schow og Kopperholdt, som kunde ophæves, naar det skulde være. Det skete imidlertid først i i 837, da Schow var gaaet af og hans Søn Georg Schow var bleven konstitueret Borgmester.

Medens den ældre Schow, som omtalt, synes at have haft Sympati for de liberale Ideer, faar man af den yngre Schow det Indtryk, at han, der hidtil havde været ansat i Regeringskontorerne paa Gottorp, var en til det yderste pligttro Embedsmand og overordentlig nidkær i Tjenesten, i hvert Fald i de Aar, han var konstitueret. Derfor tørnede han hurtigt sammen med Kopperholdt.

En Dag i Juni 1837 fik „Allgemeines Wochenblatt's“ Læsere foruden det sædvanlige Eksemplar af Bladet et litograferet Bilag. Det var et Motto, der ind-

1 Kopperholdt til Magistraten 26/4 1834. (Acta A. XVIII. Nr. 685.) 2 Magistratens Betankning ${ }^{30} / 5$ 1835. (Smst.) 3 23/6 I835. (Smst.) attorpregeringen til Schow $10 / 2$ I 835 . (S-H. Presse, 15.) Smlgn. Allg. Wochenbl. Nr. $1164 \%$ 1835. Schow til Gottorpregeringen 13/2 1835. (S-H. Presse, 15.) 
lededes med Ordene „Den sande Frihed er intet andet end Lovens Herredømme“. Dette Motto havde dannet Indledning til en Artikel i det foregaaende Nr. I 342, men Schow havde slettet det ${ }^{1}$. Paa Foranledning af Gottorpregeringen og Schow blev Kopperholdt forhørt, men han erklærede, at efter hans Mening, kunde det ikke forbydes ham at sende saa mange Breve til sine Abonnenter, som han vilde, og han var ikke pligtig til at forelægge Bilaget til Godkendelse ${ }^{2}$. Schow stillede sig paa det Standpunkt, at Kopperholdt frivilligt havde givet sig under Censur i hans Faders Tid, saaledes at han skulde sende Manuskripterne til Godkendelse for Trykningen ${ }^{3}$. Herimod protesterede Kopperholdt skarpt, idet han hævdede, at den tidligere Borgmesters Gennemsyn af Manuskriptet kun var en Venlighed mod Kopperholdt, men ikke Censur. Da Schow saa fandt en Artikel i det følgende Nr. I344 uegnet til Optagelse fordi den dadlede Regeringen og omtalte statsretslige Forhold mellem Kongeriget og Hertugdømmerne, som hellere maatte være uomtalt, strøg Schow den i Korrekturen. Han fandt den alligevel i selve Bladet, og beslaglagde derfor hele Oplaget. Kopperholdt erklærede derpaa, at han kun ønskede de i Slesvig bestaaende Presselove bragt i Anvendelse, og Schow mente, at han derefter kunde forbyde Kopperholdt alle politiske Artikler ${ }^{5}$.

Gottorpregeringen fandt dog, at Schow var gaaet for vidt, naar han vilde forbyde politiske Efterretninger, dels fordi man vanskeligt kan sige, hvilke Efterretninger der er politiske, dels fordi Bladudgiverne stiltiende har faaet Lov til at optage Politik ${ }^{6}$. Derfor fik Kopperholdt en udtrykkelig Tilrettevisning, og han truedes med, at han skulde miste sit Privilegium, hvis han i Fremtiden optog anstødelige Artikler, men videre mente Regeringen ikke, at der var Grund til at gaa denne Gang?.

Dermed kunde denne Sag være endt, hvis ikke Kopperholdt havde forbeholdt sig at indgive en Forklaring. Det er formentlig paa dette Tidspunkt, at han har overdraget Advokat Heiberg i Slesvig at tage sig af hans Sag. Heiberg havde allerede i to Aar været Sagfører for „Eckernförder Wochenblatt“ og var saaledes fortrolig med de bestaaende Presselove. Han var endvidere udpræget liberal Slesvigholstener, og som saadan kæmpede han nu i to Aar mod Myndighedernes Fremfærd mod Bladet i Aabenraa ${ }^{8}$.

1 Følgebladet ligger som Bilag til Schows Indberetning $25 / 8$ I837. (S-H. Presse, I5.) ${ }^{2}$ Ekstrakt af Aabenraa Retsprotokol ${ }^{23} / 6$ I837. (Smst.) ${ }^{3}$ Schows Indberetning $25 / 6$ 1837. (Smst.) - Kopperholdt til Schow 29/6 1837 (Smst.) Schow til Gottorpregeringen 1/7 1837. (Smst.) 4 Spies's Votum. (Smst.) 7 Gottorpregeringen til Schow $5 / 7$ 1837. (S-H. Presse, I 5.) 8 Om Heiberg henviser jeg til min Afhandling i „Sønderjydske Aarbøger" r93r. 
Heiberg gav i Kopperholdts Navn en Fremstilling af Sagen, som sendtes til Regeringen paa Gottorp, og han krævede, at Beslaget blev hævet, at Kopperholdt fik en Skadeserstatning og Schow en Irettesættelse, fordi han ikke havde opfyldt sin Embedspligt ${ }^{1}$. Besværingen forandrede imidlertid Gottorpregeringens tidligere mere velvillige Holdning. Regeringspræsident Spies mente, at der ikke skulde tages Hensyn til Besværingen, fordi Kopperholdt i 1830 havde misbrugt Pressen ved at opfordre til at bevirke de Reformer i Statsforvaltningen, som ikke billigedes "ovenfra“, „fra neden“. Senere havde der flere Gange været Grund til at gribe ind „wenn nicht humane Rücksicht auf eine bis zur Lebensgefährlichkeit krankhafte Reizbarkeit des die Aufsicht führenden Beamten eine für diese mildere Weise hätte vorziehen lassen “. Saaledes blev Kopperholdt vænnet af med Tilsyn og kunde nu ikke finde sig i strengere Forholdsregler. Spies finder imidlertid, at Kopperholdt har forhaanet Love og Embedsmænd, og selv om Spies ikke vilde have slettet de omstridte Artikler, finder han dog, at Ansøgningen fra Heiberg burde afslaas, saa meget mere som den er holdt i en usømmelig Tone ${ }^{2}$. I Overensstemmelse hermed meddeltes der Afslag paa Ansøgningen (21/7, I837).

Men Sagen var ikke sluttet endda. Kopperholdt lod Heiberg indsende en Besværing til selve Kancelliet. Han fremstillede, hvorledes Gottorpregeringen havde forbudt Fordelingen af det litograferede Blad og hævdede, at Gottorpregeringen ikke havde Myndighed til at udstede et saadant administrativt Forbud, kun Retten kan afgøre, om Loven er krænket. Gottorpregeringen kan ikke tiltage sig en lovgivende Myndighed. Heller ikke Truslen om Tab af Privilegiet mente Heiberg, at Gottorpregeringen havde Myndighed til at udstede, og derfor anmodede han om, at Reskriptet fra Gottorpregeringen maatte blive taget tilbage, og at Retten maatte faa Sagen til Afgørelse ${ }^{3}$.

Gottorpregeringen og Kancelliet drøftede Spørgsmaalet. Gottorpregeringen fremhævede de Vanskeligheder, som den kom i, naar nogle Blade viste en genstridig Tendens, thi den kunde ikke paalægge Bøder uden retslig Afgørelse, og Truslen om Tab af Privilegium kunde Gottorpregeringen ikke virkeliggøre; derfor mente den, at den maatte lægge Vægten paa at forbyde politiske Efterretninger ${ }^{4}$. Den Tanke havde været fremme hos Regeringsmedlemmerne at anklage Kopperholdt for Retten, men Retten kunde have en anden Mening, og hvis Kopperholdt blev dømt ved Underinstansen og han saa appellerede, kunde hele

1 Heibergs Ansøgning 13/7 1837. (S-H. Presse, 15.) 2 Spies's Votum 18/7 1837 . (Smst.). 3 Heibergs Besværing (udat.) (ca. 4/8). (Acta A. XVIII. Nr. 685.) Gottorpregeringen til S-H. Kancelli 29/7 1837. (S-H. Presse, I5.) 
Sagen trække i Langdrag og derved medføre Ubehageligheder. Derfor var Regeringen stemt for at undgaa retslige Afgørelser ${ }^{1}$.

Kancelliet mente, at det laa uden for Regeringens Myndighed at tildele Kopperholdt en Tilrettevisning i Spørgsmaalet om det litograferede Følgeblad, da den ikke havde anden Straf end Beslaglæggelse, men iøvrigt var det enig med Regeringen i, at det vigtigste Middel til at hindre Misbrug af Pressen var Overholdelse af Kancellipatentet af $4 / 3$ I 820 med det deri indeholdte Forbud mod politiske Artikler. ${ }^{2}$

Krigen mellem Kopperholdt og Myndighederne var dermed erklæret. Den Velvilje, han havde mødt hos den ældre Borgmester Schow, var afløst af Fjendskab hos den konstituerede Borgmester, og den Overbærenhed, som Gottorpregeringen havde vist, var, dels paa Grund af Sagen i 1830 , dels paa Grund af Heibergs kraftige Indlæg og Klage til Kancelliet, bleven erstattet af en nyvakt Agtpaagivenhed.

Den Diskussion mellem Kancelliet og Gottorpregeringen, som Sagen om Følgebladet affødte, viste, at Heiberg i Virkeligheden havde ramt et centralt Punkt, naar han krævede Sagen afgjort af Retten. Den viste, at der raadede Usikkerhed indenfor Regeringskredse i Spørgsmaalet om Tilsynet med Pressen, og hvilken Frygt navnlig Gottorpregeringen havde for at foranstalte Rettens Indgriben. Diskussionen fastslog to Ting, som blev retningsbestemmende for Myndighedernes Stilling til Kopperholdts Blad: at Gottorpregeringen havde Myndighed til at bekræfte en Beslaglæggelse, men ikke til at tildele nogen anden Straf, og at man til enhver Tid havde det Middel at forbyde Udgiveren alle politiske Efterretninger. Den yderste Straf: at fratage Udgiveren Privilegiet, kunde anvendes for meget grove Forseelser, men først efter Kongens Resolution.

Sagen havde imidlertid ogsaa medført, at Kopperholdt var kommen i Forbindelse med Heiberg og derigennem med Kredsen af liberale Mænd i Hertugdømmerne, denne Kreds, der allerede var begyndt at føle sig som et Parti og rummede Personligheder som Hiort Lorenzen i Haderslev og Olshausen i Kiel, disse Mænd, for hvem Lornsens Navn var et Bannermærke, og som i Tale og Skrift bekæmpede Enevælde og Myndighedsmisbrug.

Heller ikke i Aabenraa stod Kopperholdt alene. I 1830 havde Lornsens Skrift funden Genklang ogsaa der. Der var bleven afholdt Møder, hvor man diskuterede Spørgsmaalet om Petitioner, og Advokaterne Reuter og Bruhn samt Købmand Detlefsen havde været de ledende Mænd $^{3}$. Senere sporede vi hos Magi-

\footnotetext{
1 Gottorpregeringen til Kancelliet $29 / 8$ I 837 . (S.-H. Presse I5). ${ }^{2}$ S-H. Kanc. til Gottorpregeringen $2 / 10$ 1837. (S-H. Presse, 15.) ${ }^{3}$ Schow til Undersøgelseskommissionen ${ }^{30} / 1$ I 83 1. (Aabenraa Raadstuearkiv.)
} 
straten et Ønske om, at „Allgemeines Wochenblatt" skulde bringe politiske Efterretninger. Da Stænderne var traadt i Virksomhed, fik de liberale Krav Tag i Befolkningen. Til det første Valg til Stænderne synes der ikke at have knyttet sig særlig Interesse, men den følgende Stænderforsamling blev imødeset med Forventning. Der afsendtes Petitioner om Skattebevillingsret, Pressefrihed og Forening af Slesvigs og Holstens Stænder ${ }^{1}$. Schow kom ogsaa her paa Kant med de liberale. Da den tidligere Stænderdeputerede Lüders sammen med Lorenzen og A. H. Hartmeyer havde indbudt Borgerne i Aabenraa til et Møde paa Raadhuset, for at man kunde aftale at indsende en Petition til Kongen om snarlig Offentliggørelse af et detailleret Statsbudget, fandt Schow sig foranlediget til at forbyde Mødet for at hindre, at en saadan Petition indsendtes ${ }^{2}$.

Den 17 . August var Bladets Nr. I35I bleven beslaglagt, fordi Kopperholdt efter "Den Frisindede" havde taget en Artikel, hvori det hed, at „der hører mere til at gøre en Dag betydningsfuld for det ganske Land, end at Kongen indtager en Frokost paa Skydebanen"3. Artiklen var imidlertid ogsaa optaget i „Eckernförder Wochenblatt“; det forsømte Kopperholdt ikke at gøre opmærksom paa i sit Blads Nr. I354. Men Gottorpregeringen meddelte Borgmester Schow, at paa Grund af denne Oplysning burde Bladet have været beslaglagt, thi det stred mod en Forordning af $3 / 12$ i 830 , hvorefter der $i$ offentlige Blade ikke maatte aftrykkes Censurhuller eller Bemærkninger, der refererer sig til saadanne ${ }^{4}$. Med Rette gjorde Heiberg i hvasse Ord opmærksom paa, at det var en noget haardhændet Fortolkning af Loven ${ }^{5}$. Men det frugtede intet.

Til Gengæld begyndte de Liberale i Hertugdømmerne at lægge Mærke til „Allgemeines Wochenblatts" Stridigheder. Heibergs Besværing vandt Bifald hos Venner af Pressefriheden i Kiel, selv Professor Falck var interesseret i denne Sags Afgørelse. Man haabede paa, at Stillingen vilde vende sig til det bedre, naar Kongen var død, og at man $i$ alle Tilfælde saa kunde opnaa at Retten fik Lov at afgøre Sagen. Det var paa denne Tid, at Kopperholdt søgte Forbindelse med Hiort Lorenzen for at bede ham om Bidrag til Bladet ${ }^{6}$. Hiort Lorenzen efterkom Opfordringen, og det gav Anledning til en Forbindelse mellem de to Mænd, som bestod, saalænge Kopperholdt var i Aabenraa.

Kaarene var ikke lette for den liberale Presse; netop i Efteraaret $1837 \mathrm{blev}$

1 Allgemeines Wochenblatt, Nr. ${ }_{392} 30 / 5$ I8 38 . 2 Schow til Gottorpregeringen ${ }^{30} / 12$ I837. (Aabenraa Raadstuearkiv.) Smlgn. Allg. Wochenbl. $3 / 1{ }_{1} 8_{3} 8$. ' Schow til Gottorpregeringen 17/8 1837. (S-H. Presse, 15.) (Beslaglagt Nr. vedlagt.) "Gottorpregeringen til Schow 8/9 1837 . (Smst.) 5 Heiberg til Kancelliet $1 / 10$ 1837. (Acta A. XVIII. Nr. 685.) Hiort Lorenzen 19/10 1837. (Hiort Lorenzens Privatarkiv, Rigsarkivet.)

Kopperholdt til 
det forbudt „Eckernförder Wochenblatt“ at bringe politiske Efterretninger; man paatænkte at grunde en Presseforening, men Ideen blev ikke virkeliggjort. I Aabenraa fulgte Beslaglæggelserne Slag i Slag. Saa længe det af Politiet blev meddelt Udgiveren, hvorfor Bladet blev beslaglagt, kunde Heiberg $i$ alt Fald forsøge et Forsvar, der altid mundede ud i dette, at Beslaglæggelsessagen skulde afgøres af Retten, men da Schow erklærede, at han fremtidig ikke vilde meddele Udgiveren Aarsagen til Beslaglæggelsen"1, var Angreb og Forsvar fra Heibergs Side saa godt som umuligt.

Det er ufrugtbart i Enkeltheder at gennemgaa disse talrige Beslaglæggelser; som Eksempler skal blot anføres, at Nr. I 386 blev beslaglagt for en Omtale af Lornsens Død, Nr. 1396 for Gengivelse af en Petition om Skattebevillingsret og Stændernes Forening, Nr. I404 for en Adresse til det Mindretal i Stænderne, der stemte for Skattebevillingsret, Nr. 1407 fordi der blev gengivet nogle Skaaltaler, hvis Indhold ikke stemte med Stændertidende, idet de bl. a. gik ud paa Adskillelse af Hertugdømmernes og Kongerigets Finanser. Fra den første Beslaglæggelse i Sommeren 1837 til ro. Oktober 1838 blev 16 Numre beslaglagt. Man vil imidlertid ved at betragte denne Række Eksempler bemærke, at Beslaglæggelserne sker ud fra et ganske bestemt Synspunkt: Kampen mod den slesvigholstenske Liberalisme, saaledes som den nu var udformet til at være et Partis Anskuelser. Kampen om „Allgemeines Wochenblatt“ var altsaa ikke en Strid mellem Kopperholdt og Schow alene, den var ogsaa en Kamp mellem den unge Liberalisme og Enevældens konservativt indstillede Regeringsbureaukrati.

I det lange Løb maatte Tilstanden dog være uholdbar; de mange Beslaglæggelser vakte en for Regeringen pinlig Opsigt, og derfor begyndte den at overveje, om man ikke skulde anvende kraftigere Midler overfor Kopperholdt. Da fjorten Numre af Bladet var beslaglagt, var man klar over, at nu var det Tid at gøre Brug af den Magt, som Regeringen havde faaet tillagt ved at kræve Bladet redigeret i Overensstemmelse med dets Privilegium, altsaa uden politiske Efterretninger ${ }^{2}$. Da et Par nye Overtrædelser fra Kopperholdts Side fulgte, besluttede Regeringen at lade Forbudet mod politiske Efterretninger træde i Kraft. ${ }^{30} / 10$ meddeltes Forbudet Kopperholdt, efter at man forinden havde indhentet Kancelliets Billigelse. Virkningen deraf blev i første Omgang, at Kopperholdt besluttede fremtidig at udgive to Numre samtidig, et politisk og et upolitisk Blad. Han forsøgte at indskrænke det politiske Stof til kun at være taget

${ }^{1}$ Schow til Gottorpregeringen $28 / 11$ 1837. (S-H. Presse, 15.) 2 J. Rist's Votum $25 / 101838$. (S-H. Presse, Nr. 15.) 
fra Stændertidende, men alligevel ramte Beslaget ham - og det maatte gøre det i Henhold til hans Privilegium.

Da Prins Christian saa i November 1838 kom til Aabenraa, benyttede Kopperholdt Lejligheden til at søge Audiens hos ham. Han medbragte Korrekturen til alle de beslaglagte Blade og forklarede Prinsen den Stilling, han var i. Prinsen raadede ham til at indsende en Naadesansøgning til Kongen for at faa Forbudet mod Optagelse af politiske Artikler ophævet, men Kopperholdt afslog det med den Motivering, at Forbudet var givet af en ukompetent Myndighed og hvilede paa en forkert Udlægning af Privilegiet ${ }^{1}$.

Hvad Kopperholdt sigtede til, fremgaar tydeligt af den Besværing over Forbudet, som Heiberg indsendte til Kancelliet $5 / 1$ I $839^{2}$. Han minder indledende om Indholdet af Kopperholdts Privilegium, hvorledes det ved dette var bleven ham forbudt at optage politiske Efterretninger, og at han skulde underkaste sig Kancelliets Udlægning af Privilegiet. Men hvad det første Punkt angaar, da er det efter Heibergs Mening klart, at Kancellipatentet af $4 / 3$ I820 støtter sig paa Forordningen af 22. Februar 1820 og derfor kun angaar udenrigspolitiske Efterretninger. At det forholder sig saaledes ses ogsaa indirekte af Kancelliskrivelsen af 26. Sept. 1835, hvorefter Stænderforhandlingerne kun maatte meddeles efter Stændertidende; ved sit Forbud har Gottorpregeringen altsaa tilintetgjort hin Skrivelse. For det andet har Gottorpregeringen slet ikke Myndighed til at udstede et saadant Forbud, da det indeholder en Fortolkning af Privilegiet, som kun kan tilkomme Kancelliet.

Denne Udlægning af Privilegiets Forbud mod at optage politiske Efterretninger forklarer Heibergs og Kopperholdts Kamp mod Myndighederne, men den stred ganske mod Regeringens Anskuelse, idet den fortolkede det som gældende baade indre og ydre Politik. Heiberg havde imidlertid indanket Sagen for Kancelliet. Dets Kendelse faldt ${ }^{22} / 1$ og Forbudet mod at optage politiske Artikler stadfæstedes.

Slaget var nu i Virkeligheden tabt for Kopperholdt. Ganske vist kom Kopperholdt i Forbindelse med Orla Lehmann. I længere Tid havde de københavnske Aviser, og især „Kjøbenhavnsposten“ bragt Artikler, som berørte Pressesagen i Slesvig. Det var i den Anledning, at Lehmann gennem Kandidat Sick opfordrede Kopperholdt til at give en historisk Fremstilling af Pressesagens Forløb ${ }^{3}$. Kopperholdt følte sig smigret ved denne Henvendelse; han fremhævede, at han

1 Kopperholdt til Heiberg ${ }^{24} / 11$ I 838 . (Afskrift i Ny. Kgl. Saml. Fol. 1477. Kgl. Bibliothek.) 2 Acta A.XVIII. Nr. 685. ${ }^{3}$ Kopperholdt til Hiort-Lorenzen $2 / 11$ 1839. (Hiort-Lorenzens Privatarkiv, Rigsarkivet.) 
ikke havde gjort andet end hvad der var hans Pligt i den Sag ${ }^{1}$, men han var glad for den Bistand, som Lehmann vilde yde ham. Forbindelsen med Lehmann blev imidlertid ikke af lang Varighed, ejheller af Betydning. Et Par Artikler om de slesvigske Presseforhold, dels af Kopperholdt, dels af Lehmann ${ }^{2}$, var de synlige Resultater.

Schow var imidlertid ikke bleven mildere mod Kopperholdt, og Kopperholdt var naaet til det Punkt, hvor han blev unødvendigt udfordrende. Det viste sig ved den Maade, hvorpaa han meddelte Kancelliets Afslag af ${ }^{22} /{ }_{1}$. I det Nummer (1442), hvori Afslaget meddeltes, var Bladets „Hoved“ omgivet af en Sørgerand, og i en Note stod „Meddelt af Politiet d. 28. Januar“, som var Kongens Fødselsdag? ${ }^{3}$.

Det fik Bægret til at flyde over. Allerede 7. Januar havde Gottorpregeringen meddelt Schow, at han skulde true Kopperholdt med, at han skulde miste sit Privilegium4, og samme Dag sendte Regeringen Kancelliet en Fremstilling af Kopperholdts Forseelser i den sidste Tid ${ }^{5}$. I Tilslutning til denne Beretning fulgte d. 8. Februar en ny samlet Fremstilling af Kopperholdts Redaktørvirksomhed $^{6}$. Regeringen mindede om, hvordan Kopperholdt allerede i I 830 havde fremsat ophidsende Udtalelser, og hvordan Bladet siden fremfor alle andre havde omtalt de offentlige Anliggender paa en anstødelig Maade. Det nævntes endvidere, hvorledes Bladet havde unddraget sig Politiets forudgaaende Gennemsyn af Manuskriptet og bestandig havde vist Trods mod Politiet. De Forsøg, der havde været gjort paa at holde Kopperholdt indenfor Lovens Rammer, havde været frugtesløse, og derfor havde Flertallet af Regeringsmedlemmerne vedtaget at foreslaa, at Udgiveren skulde miste sit Privilegium.

Kopperholdt, der anede, at hans Privilegium var i Fare? ${ }^{7}$, besluttede at forsøge at unddrage sig Schows formentlige "Vilkaarlighed"s ved at lade Bladet trykke i Flensborg. Derved kunde han tillige faa Ram paa Rathje. Endnu i 1838 havde denne benyttet sig af de Vanskeligheder, som Kopperholdt havde været $i$, idet han havde ansøgt endnu engang om at faa et Bladprivilegium $^{9}$, men han havde faaet Afslag ${ }^{10}$. Nu kunde Kopperholdt skrive triumferende:

1 Kopperholdt til Lehmann ${ }^{12} / 1$ 1839. (Ny kgl. Saml. Fol. 1477. Kgl. Bibl.) ${ }^{2}$ Kjøbenhavnsposten, Nr. 17 og 39, 1839. ${ }^{8}$ Nummeret ligger som Bilag til Beretning fra Schow. (Aabenraa Raadstuearkiv.) "Aabenraa Raadstuearkiv. ${ }^{5}$ Acta A. XVIII, Nr.695. ${ }^{6}$ Smst. ${ }^{7}$ Kopperholdt til Hiort Lorenzen $1 / 3$ 1839. (Hiort Lorenzens Privatarkiv, Rigsarkivet.) ${ }^{8}$ Kopperholdt til Orla Lehmann $8 / 8$ 1839. (Ny kgl. Saml. Fol. 1477, Kgl. Bibl.) ' Rathjes Ansøgning, $2 / 51838$ (Acta A. XVIII, Nr. 685. 10 18/5 1838 (Smst.). 
„Herr Bogtrykker Rathje!

26. Februar 1839, Flensborg.

Jeg indser, kære Rathje, Omfanget af det Tab, der opstaar for Dem og Deres Familie ved vor Overenskomsts Ophør. Men de Grunde, som har bevæget mig til fremtidig at lade mit Blad trykke her, er for tungtvejende for mig til at jeg desuagtet kan være tvivlraadig. Gud give Dem snarlig Erstatning for en saa uventet Indskrænkning af Deres Indtægter; og vær overbevist om, at jeg vil glæde mig over lejlighedsvis at kunne bidrage mit dertil.

Deres hengivne

Kopperholdt. ${ }^{* 1}$

Rathje beraabte sig imidlertid paa, at Kontrakten med Kopperholdt gjaldt til Udgangen af $1839^{2}$. Men i den Sag blev der aldrig truffen nogen Afgørelse. 26. Februar 1839 havde Kancelliet indgivet en Forestilling til Kongen og i Overensstemmelse med Gottorpregeringens Ønske andraget om, at Kopperholdt skulde miste sit Privilegium ${ }^{3}$. Den 2. Marts 1839 resolverede Kongen, at Kopperholdts Privilegium skulde kasseres.

Et Afsnit af Aabenraa Pressens Historie var afsluttet. Ved at beskæftige sig med det, har man set, hvilken Modstand den havde at kæmpe imod. Det var ikke saa meget fordi den var slesvigholstensk, som for dens Liberalismes Skyld, at Myndighederne slog den ned. Det nationale spillede endnu ikke nogen væsentlig Rolle. Derfor havde Kopperholdt med saa stor Tillid kunnet nærme sig Orla Lehmann, derfor følte han Sprogsagen som noget ulyksaligt og skæbnesvangert, derfor saa han i „Dannevirke“ et Blad, der var kaldt til Live af „Tvedragtens Djævel". Han forstod ikke, saalidt som de andre slesvigholstenske liberale, hvad det var der bar den nye Aandsstrømning, den folkelige Danskhed, der nu skød sig ind over Nordslesvig, og som snart skulde mærkes i selve Aabenraa, og der forkyndes af hans Efterfølger som Redaktør, af Krøblingen Frederik Fischer.

1 Bilag til Rathjes Skrivelse til Schow $27 / 2$ I839. (Aabenraa Raadstuearkiv.) 2 Rathje til Schow ${ }^{27} / 2$ I839. (Smst.) ${ }^{3}$ Acta A. XVIII, Nr. 685 . 